\title{
Perancangan Arsitektur RESTful pada Integrasi Data Refrensi Buku di Perpustakaan Daerah dan Perpustakaan Universitas (Studi Kasus: Kota Salatiga)
}

\author{
Erwien Christianto \\ Faculty of Information Technology Satya Wacana Christian University \\ Jl. Diponegoro 52-60, Salatiga 50771, Indonesia \\ erwinchristiant@gmail.com,
}

Joko Santosa

Faculty of Information Technology Satya Wacana Christian University

Jl. Diponegoro 52-60, Salatiga 50771, Indonesia

joekelir@gmail.com,

\begin{abstract}
The library in this modern era in the advancement of information technology needs to be developed towards data integeration. Network communication between libraries can be a means of good learning, effective and efficient. The problem often encountered in collaborating on the business process for integeration of library data is the difference of application to the user of each part. Technology that can integrate data even though different applications / platforms on end users with web service technology. With the web service for RESTFul method can bridge the integration of data exchange for book refrence in library so that can be know where and where book have references to references book or document needed. Restful technology is created with java class and database as prototype and simulation. Clear and viable business processes can be integrated into an integrated information system.
\end{abstract}

Keywords: Web service, Restful, Integration, Reference Book 


\section{Pendahuluan}

\section{Latar Belakang}

Teknologi internet telah maju dalam perkembangan sistem distributed computing dengan munculnya konsep mengenai web services. Web services merupakan salah satu paradigma baru dalam mengimplementasikan sistem terdistribusi melalui web yang menggunakan basis teknologi XML, dengan standard protokol HTTP dan SOAP. Dari standard yang digunakan dalam mendukung teknologi web services, maka implementasi Web services menjanjikan banyak kemudahan dan perbaikan dalam mendukung integrasi berbagai platform system dan aplikasi, baik melalui infrastruktur intranet atau skstranet. Keuntungan utama dari integrasi sistem informasi adalah memperbaiki arus informasi dalam sebuah organisasi.

Sebuah organisasi khususnya Perpustakan sebagai salah satu institusi pelayan masyarakat akan melayani tranksaksi penminjaman buku dalam kesehariannya. Pemberian layanan dan tindakan dalam banyak hal akan mempengarui pemninjam. Semakin cepat akan semakin baik karena menyangkut peminjam dalam menemukan tempat buku refrensi berada. Semakin besar jasa layanan suatu perpustakan, akan semakin kompleks pula jenis tindakan dan layanan yang harus diberikan yang kesemuanya harus tetap dalam satu koordinasi terpadu. Karena selain memberikan layanan, perpustakan juga harus mengelola buku baik katalog dan refrensi buku untuk menentukan kaitan buku refrensi itu berada di perpustakan mana. Melihat situasi tersebut, sudah sangatlah tepat jika perpustakan harus menggunakan sisi kemajuan komputer, baik piranti lunak maupun perangkat kerasnya dalam upanya membantu penanganan manajemen yang sebelumnya belum dilakukan. RESTful adalah suatu model arsitektural untuk membangun solusi enterprise berdasarkan service. Secara lebih spesifik, REST berhubungan dengan pembangunan independen dari layanan bisnis yang dapat dikombinasikan menjadi proses bisnis pada level tinggi dan solusi dalam konteks enterprise.

Berdasarkan latar belakang yang ada, penelitian ini bertujuan untuk merancang pencarian buku refrensi dengan pemanfaatan web service dengan 
metode RestFul yang dapat mengkomunikasikan data antar perpustakaan daerah dan perpustakaan universitas atau perpustakaan pada fakultas. Perancangan ini dibangun untuk memudahkan bagian pustakawan dalam melakukan pencarian lokasi buku/jurnal apa saja yang menjadi keterkaitan dalam buku refrensi yang di cari/dibutuhkan.

\section{Tinjauan Pustaka}

Ada beberapa penlitian sebelum yang diambil sebagai acuan perbandingan atau membedakan dengan temuan penelitian yang dilakukan:

Penelitian lain juga dilakukan dalam perancangan library automation dengan metode rapid application development (RAD) menerapkan RESTful Web service menggunakan AsyncTask. Untuk hasilnya library automation berbasis mobile yang interaktif dan mudah digunakan oleh civitas akademik Universitas Negeri Semarang yang dapat menghasilkan menu pelacakan koleksi, riwayat koleksi yang pernah dilakukan, dan perhitungan denda keterlambatan pengembalian pustaka. ${ }^{1}$

Data integrasi kebutuhan harga pokok dalam suatu proses bisnis perusahan garment menggunakan Service Orientied Arcitecture (SOA). Menghasilkan point-point yang dibutuhkan tiap bagian dan setiap bagian akan menginiformasikan hasil dan di olah oleh web service untuk menghasilkan harga pokok penjualan. ${ }^{2}$

${ }^{1}$ Elham Yudhistira, Aji Purwinarko, and Indah Urwatin Wusqo, "Implementasi Restful Web Service Menggunakan AsyncTask Pada Aplikasi Library Automation Berbasis Android," no. Snik (2016): 286-92, https://www.researchgate.net/profile/Aji_Purwinarko/publication/310441851_Implementasi_ Restful_Web_Service_Menggunakan_AsyncTask_pada_Aplikasi_Library_Automation_Berbasis_ Android/links/582d2f3308ae102f072a1f5c/Implementasi-Restful-Web-Service-Menggunakan-.

${ }^{2}$ Erwien Christianto, Wiranto Utomo, and Wiwin Sulistyo, "Data Integration of Cost Materials Needs through a Service Oriented Architecture (Study Case: Pt X Garment Ungaran)," Journal of Advanced Computer Science \& Technology 4, no. 1 (2015): 136-47, https://doi.org/10.14419/jacst. v4i1.4309."ISSN" : "2227-4332", “abstract": "Data processing is an important part of a garment company. With increasingly complex and developing a garment company, data processing and integration became a very important requirement. The need for data integration in determining the cost of materials becomes a very important part in the garment industry. Data distribution or dissemination from one to another section gives results in data duplication, so that it may cause the data to be inconsistent. In addition, the efficiency of the process in determining the cost of materials is highly needed to achieve the selling price determination target. Nowadays, there is web-based technology, which is capable of 
Untuk memperoleh Informasi penelitian perguruan tinggi harus mengunjungi web site masing-masing perguruan tinggi. Karena masingmasing perguruan tinggi mempublikasikan informasi penelitianya sendirisendiri. Usaha yang sudah ada untuk mengintegrasikan informasi penelitian dengan cara menyamakan format data, tetapi kurang berhasil. Informasi penelitian dapat juga dicari melalui search engine, tetapi informasi yang dihasilkan tercampur dengan informasi lain. Masalah yang sada dapat dilakukan dengan cara mengintegrasikan aplikasi dalam masing-masing bidang di perpustakaan sebagai sumber informasi penelitian dalam menerapkan web service. Mengintegrasikan tiga jenis basis data perpustakaan yang berbeda platform menggunakan tiga web service yang berbeda ke dalam satu aplikasi berbasis web. ${ }^{3}$.

\section{a. Buku Refrensi}

Kata referensi berasal dari inggris reference dan merupakan kata kerja to refer yang artinya menunjukan kepada. Buku referensi adalah buku yang dapat memberikan keterangan topik perkataan,tempat,peristiwa,data statistika, pedoman, alamat, nama orang,riwayat orang-orang terkenal. pelayanan referensi adalah pelayanan dalam menggunakan buku-buku referensi. di perpustakaan biasanya buku-buku referensi di kumpulkan tersendiri dan di sebut "koleksi referensi" sedangakan ruang tempat penyimpanan disebut ruang referensi. Buku-buku referensi yang karena sifatnya sebagai buku penunjuk, harus selalu tersedia di perpustakaan sehingga dapat di pakai oleh setiap orang pada setiap saat.

Disebut koleksi rujukan karena merupakan sebuah buku atau kumpulan buku yag didesain untuk dikonsultasikan atau diacu dari masa ke masa untuk mencari informasi khusus tentang suatu topik, tema, peristiwa, orang, tempat ataupun kata-kata. Koleksi referensi bertujuan untuk

\footnotetext{
handle data integration service, called SOA (Service Oriented Architecture

${ }^{3}$ Andik Wijanarko, Irya Wisnubhadra, and Benyamin L Sinaga, "Integrasi Informasi Penelitian Pada Perpustakaan Perguruan Tinggi Berbasis Web Service," 2013, 7-12, https://www.google. $\operatorname{co.id} / \mathrm{url}$ ? $\mathrm{sa}=\mathrm{t} \& \mathrm{rct}=\mathrm{j} \& \mathrm{q}=\&$ esrc $=\mathrm{s} \&$ source $=$ web $\& \mathrm{~cd}=1 \& \mathrm{cad}=\mathrm{rja} \& u a c t=8 \& v e d=0 \mathrm{ahUKEwjE5} \mathrm{pTEwL}$ jLAhUmIqYKHTE1BGcQFggZMAA\&url=http://e-journal.uajy.ac.id/341/1/0MTF01462.pdf\&usg= AFQjCNEEIBJ4K24hjwrewtnXbSvJWoVTxQ\&sig2=Wmy_qud3RGa9FX6R11Gwog\&bvm=bv.116.
} 
memberikan informasi kepada pengguna, baik informasi bersifat ilmiah untuk kepentingan studi atau riset maupun informasi lain yang bersifat non-ilmiah.

Menurut Zainuddin (1996:21) dijelaskan bahwa:

A collection of books and other materials in a library useful for supplying information, kept together for convenience and generally not allowed to be circulated. (Suatu koleksi yang terdiri atas buku-buku dan bahan-bahan pustaka lain yang terdapat dalam sebuah perpustakaan yang sepenuhya digunakan bagi penyediaan informasi, diolah untuk memudahkan penelusuran bagi pengguna dan biasanya tidak untuk dipinjamkan).

Koleksi referensi tidak digunakan untuk dibaca secara keseluruhan atau terus-menerus seperti halnya buku teks, tetapi haya dibaca pada bagian informasi yag dibutuhkan saja. Koleksi referensi juga tidak dapat dipinjamkan untuk dibawa pulang melainkan hanya dapat dibaca saja ${ }^{4}$.

Menurut Sulistyo-Basuki (1993:437),. Adapun ciri-ciri koleksi referensi adalah sebgai berikut:

a. Buku referensi ditujukan untuk keperluan konsultasi. Lazimnya hanya bagian tertentu saja yang digunakan untuk suatu kepentingan.

b. Buku referensi tidak dimaksudkan untuk dibaca seperti buku biasa.

c. Buku referensi serig kali terdiri dari entri yang terpotong-potong. Masingmasing entri tidak sama panjangnya. Dengan kata lain buku Universitas Sumatera Utara 10 referensi biasanya ditandai dengan pemaparan buku referens yang tidak berkesinambungan.

d. Di perpustakaan buku referensi biasanya tidak dipinjamkan karena buku tersebut diperlukan setiap waktu untuk dikonsultasi. Pustakawan tidak dapat menduga bilamana sebuah buku referensi diperlukan sehingga peggunaannya terbatas pada ruang referensi saja.

e. Informasi disusun untuk memudahkan penelusuran secara cepat dan menyeluruh. Susunan ini dapat menurut abjad, judul, subjek, atau kronologis disertai indeks untuk keperluan temu balik informasi.

${ }^{4}$ Ramdani, "Pemanfaatan Koleksi Referensi Sebagai Sumber Daya Perpustakaan Dalam Jasa Layanan Informasi : Studi Kasus Pada Perpustakaan Mahkamah Konstitusi Republik Indonesia,” 2010. 
Walaupun terdapat ciri-ciri buku referensi seperti di atas dalam praktik sehari-hari, batas antara buku referensi dengan buku biasa sangatlah berbeda. Keputusan untuk menentukan apakah sebuah buku termasuk buku referensi atau buku yang akan dipinjamkan itu tergantung pada masingmasing perpustakaan. ${ }^{5}$

\section{b. Web service}

Web Service adalah suatu sistem perangkat lunak yang dirancang untuk mendukung interaction and interoperability antar sistem pada suatu jaringan. Web service digunakan sebagai suatu fasilitas yang menyediakan layanan (dalam bentuk informasi atau data) kepada sistem lain Hal ini dikarenakan web services dibangun diatas protokol-protokol yang sudah terkenal dan memiliki platform yang independent, seperti HTTP, XML, UDDI, dan WSDL ${ }^{6}$. SOA menggunakan protokol-protokol tersebut sebagai komponen kunci karena protokol-protokol menyediakan layanan yang dapat ditemukan dan digunakan secara dinamis, sehingga dapat berinteraksi dengan sistem tersebut melalui layanan-layanan yang disediakan. Web service menyimpan data informasi dalam format JSON atau XML, sehingga data ini dapat diakses oleh sistem lain walaupun berbeda platform, sistem operasi, dan bahasa pemrograman. ${ }^{7}$

\footnotetext{
${ }^{5}$ Ahmad Isywarul Mujab and Ary Setyadi, “Persepsi Pemustaka Terhadap Sikap Pustakawan Dalam Layanan Referensi Di Perpustakaan Universitas Katolik Soegijapranata" 4, no. 2 (2015).

${ }^{6}$ Eric Newcomer, Understanding Web Services: XML, WSDL, SOAP, and UDDI, 2004, http:// restfulwebapis.org/RESTful_Web_Services.pdf.applications at different network locations can be integrated to function as if they were part of a single, large software system. Examples of applications made possible by Web services include automated business transactions and direct (nonbrowser

7 Thomas Erl, Service-Oriented Architecture: A Field Guide to Integrating XML and Web Services, Prentice Hall, 2004, http://scholar.google.com/scholar?hl=en\&btnG=Search\&q=intitle:Serv ice-Oriented+Architecture+A+Field+Guide+to+Integrating+XML+and+Web+Services\#6.
} 


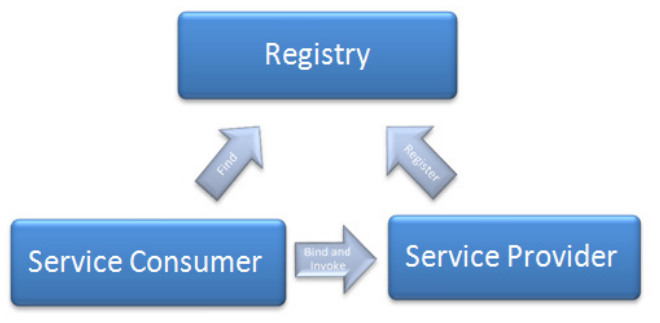

Gambar 1. Proses Web service (Erl, 2004)

Berikut penjelasan tentang proses yang terjadi pada web service:

a. Proses pencarian layanan (find). Proses ini dilakukan oleh service consumer terhadap server yang memiliki daftar layanan yang dapat digunakan serta cara untuk menggunakannya.

b. Proses menggunakan layanan (bind and invoke). Proses ini dilakukan apabila aggreement antara service consumer dan service provider telah didaftarkan pada registry server.

c. Proses register. Proses ini dilakukan oleh service provider untuk mendaftarkan service yang dapat digunakan oleh service consumer pada registry server.

d. Service contract. Bagian ini adalah antarmuka service yang mendefinisikan komponen-komponen yang terdapat pada sebuah service. Service contract direpresentasikan dalam bentuk WSDL. WSDL adalah sebuah deskripsi bahasa yang dapat dimengerti oleh manusia dan mesin komputer. WSDL ditulis dengan menggunakan sintaks XML dan digunakan sebagai antarmuka untuk melakukan message exchange dalam suatu layanan. Contoh komponen-komponen yang terdapat pada service contract adalah nama layanan, nomor versi, header ${ }^{8}$.

\section{c. Bisnis Proses}

Suatu perusahaan dalam perkembangan dan persaingannya harus menjadi semakin siap dan matang dalam menjalankan aktivitas bisnisnya.

${ }^{8}$ Erl. 
Untuk mencapai kondisi tersebut, sebuah perusahaan harus senantiasa mempertimbangkan dan mengoptimasi cara mereka menjalankan bisnis dan mengubah sistem informasi dan aplikasi untuk mendukung perubahan yang dilakukan pada proses bisnis mereka. Berikut adalah beberapa definisi proses bisnis.

1. Business process represent the unique ways in whit organization coordinate and knowledge to produce a product or service ${ }^{9}$

2. A business process is a set of logically related tasks performed to achieve a defined business outcome. Within the business process, people, wquipment, material resources, and business procedures and combined to produce a specified result ${ }^{10}$

3. Increases in consumer requirements for both product and service efficiency and effectiveness has resulted in business process reengineering (BPR). The reengineering of business processes is concerned with fundamentally rethinking and redesigning business processes to obtain dramatic and sustaining improvements in quality, cost, service, lead-times, outcomes, flexibility and innovation. ${ }^{11}$.

4. Business Process didefinisikan sebagai sebuah kumpulan dari pekerjaanpekerjaan yang saling berhubungan untuk menyelesaikan suatu permasalahan. Sebuah business process dapat dipecah menjadi sekumpulan sub-proses yang mempunyai atribut masing-masing, namun tetap berkontribusi untuk melaksanakan tujuan dari proses utama. Business process merupakan inti dari seluruh aktivitas pada suatu perusahaan atau organisasi. Untuk mencapai tujuan perusahaan, business process yang akan memberdayakan seluruh sumber daya yang ada pada perusahaan. Tapi yang perlu diketahui adalah bahwa setiap bisnis memiliki proses masing-masing yang unik, sesuai dengan karakteristik dari perusahaan

\footnotetext{
${ }^{9}$ Kenneth Laudon and Jane P. Laudon, Management Information Systems, Global Edition, 2013, http://www.myilibrary.com/?ID=523735.

${ }^{10}$ Roger S. Pressman and Bruce R. Maxim, Software Engineering: A Practitioner'S Approach., 2015, https://downloadnema.com/wp-content/uploads/2017/02/Software Engineering A Practitioner's Approach eighth edition-(www.downloadnema.com).pdf.

${ }^{11}$ F. Caeldries, "Reengineering the Corporation: A Manifesto for Business Revolution.," Academy of Management Review 19, no. 3 (1994): 595-600, https://doi.org/10.5465/AMR.1994.9412271824.
} 
dan bidang usahanya, seperti proses pembuatan produk ataupun layanan baru, pengadaan supply, menjawab pertanyaan pelanggan, ataupun rekruitasi karyawan baru, yang tentunya memiliki perbedaan karekteristik tersendiri untuk setiap perusahaan ${ }^{12}$.

Sistem informasi dapat membantu suatu organisasi dalam mencapai efisiensi dengan cara mengotomatisasi bagian-bagian dari proses bisnis atau dengan menbantu organisasi memikirkan kembali dan mempersingkat proses bisnis tersebut, jadi dalam hal ini proses bisnis dapat diimplementasikan menjadi suatu sistem informasi berbasis komputer. Untuk keperluan tersebut maka dibutuhkan sistem analis yang bertugas mempelajari permasalahan dan kebutuhan dari organisasi untuk menentukan bagaimana orang, data, proses, komunikasi, dan teknologi informasi yang diterapkan dalam bisnis tersebut ${ }^{13}$.

\section{d. RestFul}

Representational State Transfer yang disingkat REST yang merupakan arsitektur untuk penerapan web service dalam menerapkan konsep perpindahan antar state ${ }^{14}$. State disini dapat digambarkan seperti peramban meminta suatu halaman situs, di sisi server akan mengirimkan state halaman situs yang sekarang ke peramban. Navigasi melalui URL yang disediakan sama halnya dengan mengganti state dari halaman situs. Sama seperti REST bekerja, dengan bernavigasi melalui link HTTP untuk melakukan aktivitas tertentu. Seakan-akan terjadi perpindahan state antara satu dengan yang lain. Perintah HTTP yang bisa digunakan dalam REST adalah fungsi GET, POST, PUT atau DELETE. REST WS membangun integrasi dengan cara yang lebih ringan dan sederhana, dan berfokus pada sumberdaya ${ }^{15}$. Dalam pengaplikasiannya, REST lebih banyak digunakan pada web service yang

${ }^{12}$ Ian Dallas and Moe Thandar Wynn, "Information Systems for Small and Medium-Sized Enterprises," 2014, 25-47, https://doi.org/10.1007/978-3-642-38244-4.

${ }^{13}$ Pedro Sousa et al., "Applying the Zachman Framework Dimensions to Support Business Process Modeling," Digital Enterprise Technology, 2005, 359-66, https://doi.org/10.1007/978-0-387-49864-5.

${ }^{14}$ Jose Sandoval, RESTful Java Web Services: Master Core REST Concepts and Create RESTful Web Services in Java, vol. 11, 2009, https://books.google.com/books?id=NS6FeLs6hwMC\&pgis=1.

${ }^{15}$ Penidas Fiodinggo Tanaem, "RESTFul Web Service Untuk Sistem Pencatatan" 2, no. April (2016): 2443-2229. 


\section{berorientasi data sumber daya. Sebutan untuk web service yang menerapkan arsitektur REST adalah RESTful web service. ${ }^{16}$}

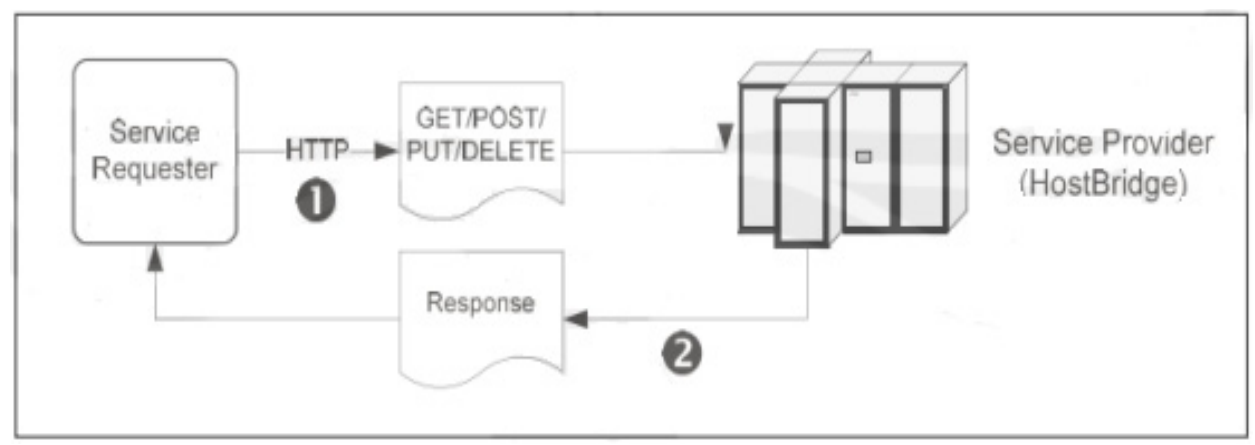

Gambar 2 : Model dasar RESTful Web services ${ }^{17}$

${ }^{16}$ Cesare Pautasso, O. Zimmermann, and Frank Leymann, "Restful Web Services vs. 'Big'web Services: Making the Right Architectural Decision," Proceeding of the 17th International Conference on World Wide Web, 2008, 805-814, https://doi.org/10.1145/1367497.1367606.we also show that there are significant differences in the consequences of certain decisions in terms of resulting development and maintenance costs. Our comparison helps technical decision makers to assess the two integration styles and technologies more objectively and select the one that best fits their needs: REST is well suited for basic, ad hoc integration scenarios, WS-* is more flexible and addresses advanced quality of service requirements commonly occurring in enterprise computing.," "author": [ \{ "dropping-particle": "”, "family" : "Pautasso", "given": "Cesare", "non-dropping-particle" : "', "parse-names" : false, "suffix": "” \}, \{ "droppingparticle" : "”, "family" : "Zimmermann", "given" : "O.," "non-dropping-particle" : "', "parse-names" : false, "suffix": " " \}, \{ "dropping-particle" : "', "family": "Leymann", "given": "Frank", "non-dropping-particle" : “", "parse-names" : false, "suffix" : "” \} ], "container-title" : "Proceeding of the 17th international conference on World Wide Web", "id": "ITEM-1", "issued" : \{ "date-parts" : [ [ "2008”] ] \}, "page": "805। u2013814", "title" : "Restful web services vs. "big'web services: making the right architectural decision", "type" : "article-journal” \}, "uris" : [ "http://www.mendeley.com/documents/?uuid=7dd92f1cf-c9e2-4afcaddf-d979f0b3a449" ] \} ], "mendeley" : \{ "formattedCitation" : "Cesare Pautasso, O. Zimmermann, and Frank Leymann, Iu201cRestful Web Services vs. Iu2018Biglu2019web Services: Making the Right Architectural Decision, $\mid \mathrm{u} 201 \mathrm{~d}<\mathrm{i}>$ Proceeding of the 17th International Conference on World Wide Web</i>, 2008, 805\u2013814, https://doi.org/10.1145/1367497.1367606.", "plainTextFormattedCitation" : "Cesare Pautasso, O. Zimmermann, and Frank Leymann, |u201cRestful Web Services vs. |u2018Big| u2019web Services: Making the Right Architectural Decision, lu201d Proceeding of the 17th International Conference on World Wide Web, 2008, 805\u2013814, https://doi.org/10.1145/1367497.1367606.", "previouslyFormattedCitation": "Cesare Pautasso, O. Zimmermann, and Frank Leymann, lu201cRestful Web Services vs. |u2018Biglu2019web Services: Making the Right Architectural Decision, lu201d $<\mathrm{i}>$ Proceeding of the 17th International Conference on World Wide Web $</ \mathrm{i}>, 2008,805 \backslash \mathrm{u} 2013814$, https://doi.org/10.1145/1367497.1367606." \}, "properties" : \{\}, "schema” : "https://github.com/citationstyle-language/schema/raw/master/csl-citation.json" \}

${ }^{17}$ HostBridge Technology, "Choosing Formal and Informal Web Services for," in SOAP and REST: Choosing Formal and Informal Web Services for CICS Integration, 2009, https://www.hostbridge. 


\section{Metode Penelitian}

\section{Analisa Lingkungan Masalah}

Penelitian di Perpustakaan ini karena terdapat beberaapa unit dilingkungan perpustakan yang masing - masing unit memiliki sistem yang berbeda kebutuhan tiap-tiap unit. terkumpul dari hasil wawancara mendesain arsitektur yang dibangun. Dengan tujuan untuk melihat lebih jauh berbagai komponen yang dipakai pada sistem yang digunakan adalah informasi, hardware, software manusia yang tersedia di lingkungan perpustakaan. Sistem yang menghasilkan desain fungsional. Desain sistem berupa desain konseptual dari sistem dengan tujuan yaitu menghasilkan spesifikasi yang sesuai dengan kebutuhan pengguna. Konsep arsitektur yang digunakan pada sistem pencarian di perpustakaan dituangkan pada gambar Gambar 3.

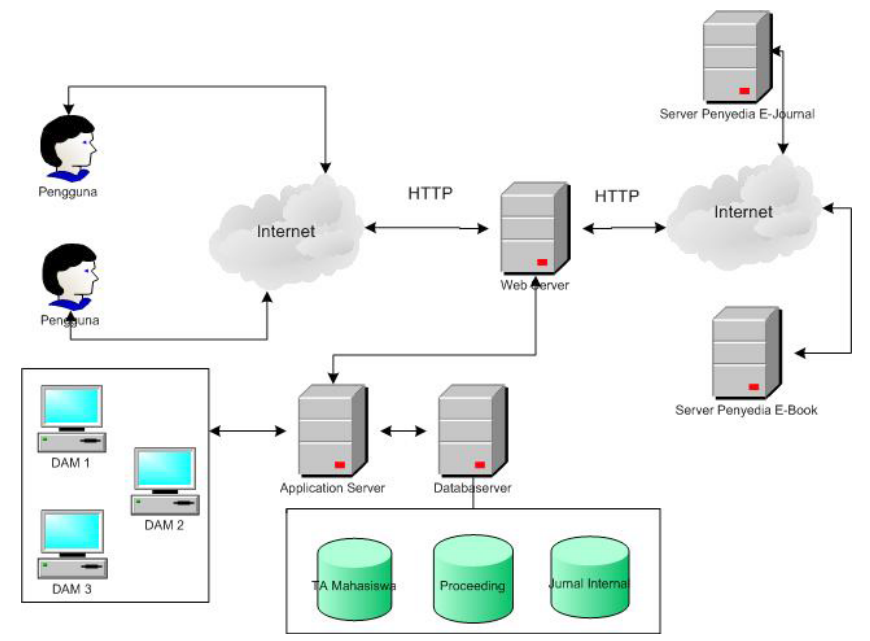

Gambar 3. Rancangan Arsitektur Perpustakaan Digital Perguruan Tinggi (Pendit, 2007)

Arsitektur tersebut terdiri atas lapisan Business Logic dan data Access berfungsi untuk memproses setiap komunikasi (POST, GET, PUT dan DELETE). Pada penerapannya, menerjemahkan setiap request HTTP dari

com/images/uploads/WP_HostBridge_SOAP_and_REST_090303.pdf. 
client. Sedangkan mengimplementasikan fungsionalitas inti dari sistem, dan merangkum logika bisnis yang relevan. Lapisan data access berperan untuk mengekspos data berdasarkan batasan batasan yang dimiliki oleh sistem. Data atau informasi yang diekspos menggunakan format data JSON. Jason adalah bahasa independen dan berdasarkan koleksi pasangan key/value dan mempunyai list value. Struktur ini memungkinkan untuk digunakan dalam setiap bahasa pemrograman modern yang membuatnya menjadi pilihan yang baik untuk berkomunikasi di dunia web. ${ }^{18}$

\section{Proses Bisnis Pencarian}

Proses bisnis utama (primary processes) pada perpustakaan umumnya meliputi proses-proses inti yang berupa pelayanan dasar pada pengguna. Proses bisnis ini dimulai dari pengadaan situs dan penginputan data koleksi dari berbagai sumber, pengelolaannya, sampai pada aktivitas pelayanan pengguna.

${ }^{18}$ Pautasso, Zimmermann, and Leymann, “Restful Web Services vs. 'Big’web Services: Making the Right Architectural Decision.” we also show that there are significant differences in the consequences of certain decisions in terms of resulting development and maintenance costs. Our comparison helps technical decision makers to assess the two integration styles and technologies more objectively and select the one that best fits their needs: REST is well suited for basic, ad hoc integration scenarios, WS- ${ }^{*}$ is more flexible and addresses advanced quality of service requirements commonly occurring in enterprise computing., " "author" : [ \{ "dropping-particle" : "”, "family" : "Pautasso", "given": "Cesare", "non-dropping-particle" : "”, "parse-names" : false, "suffix" : "” \}, “dropping-particle" : "”, "family" : “Zimmermann", "given" : "O., "non-dropping-particle" : "”, "parse-names" : false, "suffix" : "” \}, \{ "dropping-particle" : "”, "family" : "Leymann", "given” : "Frank", "non-dropping-particle" : "”, "parsenames" : false, "suffix" : "” \} ], "container-title" : "Proceeding of the 17th international conference on World Wide Web", “id" : "ITEM-1", "issued" : ‘ “date-parts" : [ [ "2008”] ] \}, "page" : "805\u2013814", "title" : "Restful web services vs. 'big'web services: making the right architectural decision", "type" : "article-journal" \}, "uris" : [ "http://www.mendeley.com/documents/?uuid=7d92f1cf-c9e2-4afc-addfd979f0b3a449"] \} ], "mendeley" : \{ “formattedCitation" : "Pautasso, Zimmermann, and Leymann, I u201cRestful Web Services vs. Iu2018Biglu2019web Services: Making the Right Architectural Decision.I u201d", "plainTextFormattedCitation" : "Pautasso, Zimmermann, and Leymann, lu201cRestful Web Services vs. Iu2018Biglu2019web Services: Making the Right Architectural Decision.|u201d”, "previouslyFormattedCitation": "Pautasso, Zimmermann, and Leymann, lu201cRestful Web Services vs. |u2018Big|u2019web Services: Making the Right Architectural Decision.lu201d” \}, "properties" : \{\} , "schema" : "https://github.com/citation-style-language/schema/raw/master/csl-citation.json" \} 


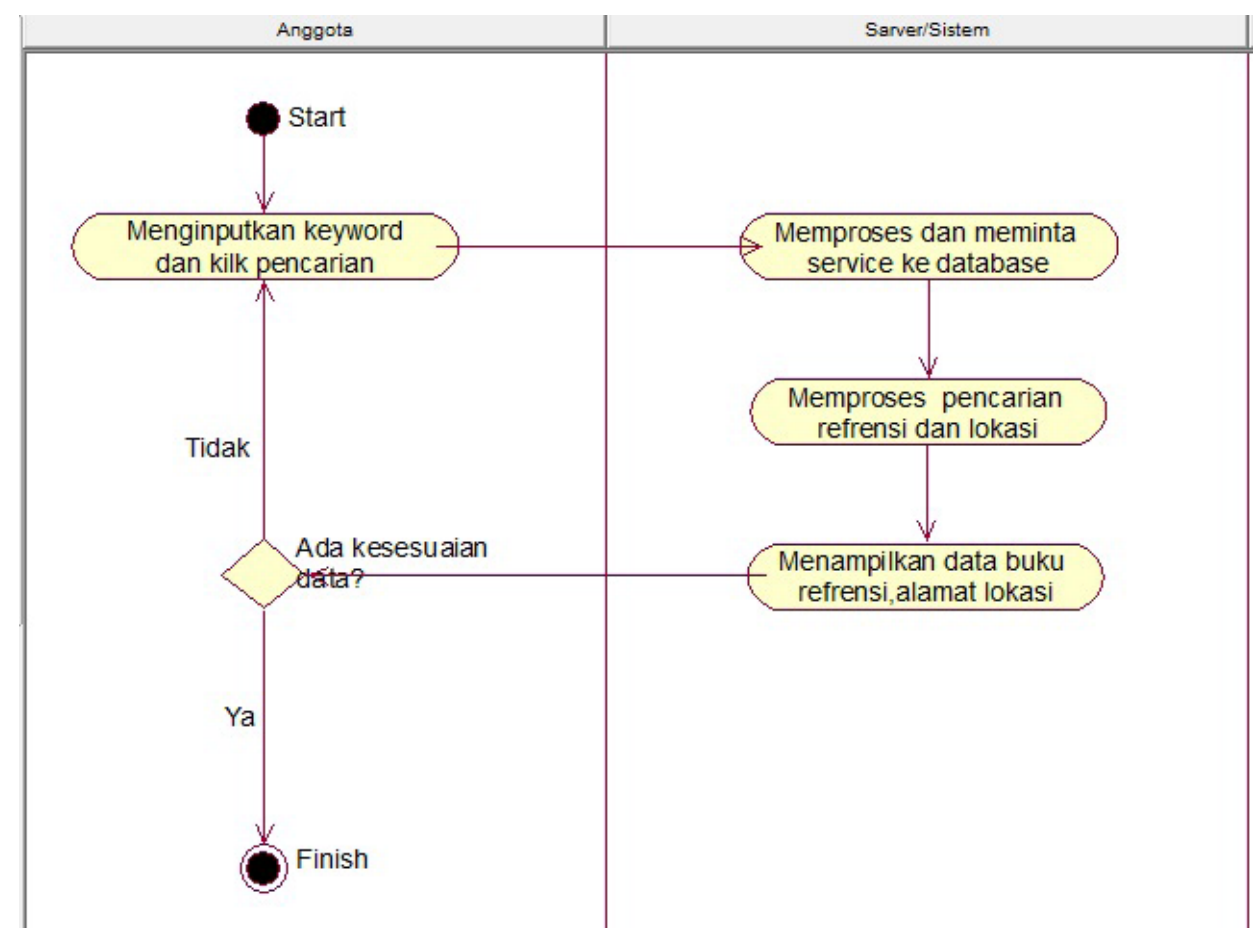

Gambar 4. Proses Bisnis Pencarian Buku Refrensi

\section{Desain Arsitektur}

Desain dari client dan sarver yang berkomunkasi yang menggunakan protokol HTTP untuk pertukaran data. Dengan rest server yang sebagai penyedia jalur akses resource atau data dan dari sisi REST client yand dapat melakukan resoruce dan kemudian menampilkan atau mengunakanya baik dari XML/Jason. 


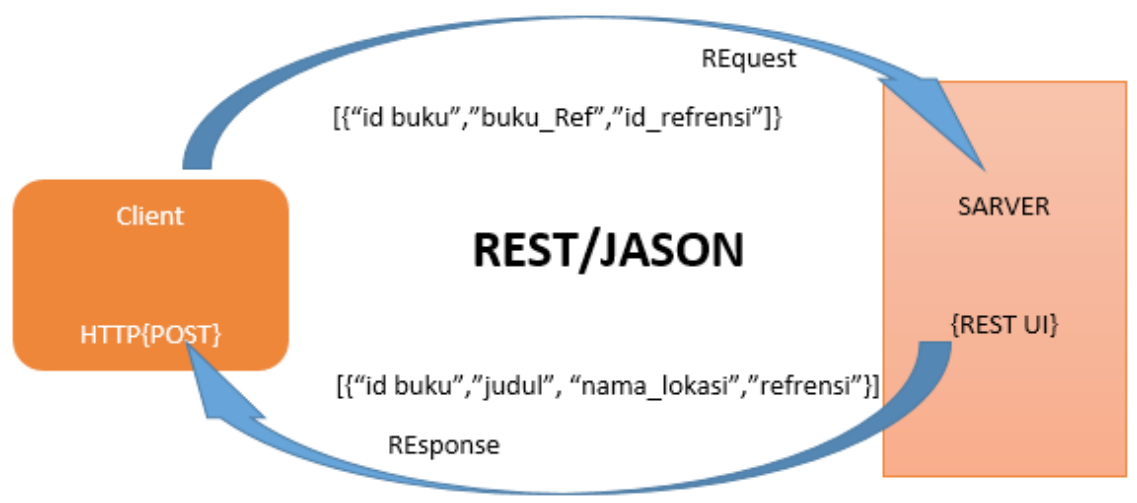

Gambar 5. Desain Arsitektur Buku Refrensi

\section{Hasil Penelitian Dan Pembahasan}

\section{Use Case Diagram}

Setiap langkah dalam use case adalah sebuah elemen dalam interaksi antara actor dan sistem. Setiap langkah harus berupa pernyataan sederhana dan dengan jelas menunjukkan siapa yang menjalankan langkah tersebut. Use case adalah abstraksi dari interaksi antara system dan aktor. Analisis dengan menggunakan model use case, memberikan keleluasaan antara peneliti dan user untuk dapat menganalisa area permasalahan, sehingga interaksi antara user dengan sistem dapat dianalisa secara keseluruhan selama proses pengembangan sistem. Syarat-syarat yang diperlukan dalam pembuatan model use case adalah aktor, use case serta komunikasi hubungan antara aktor dengan use case. Penggambaran use case dengan relationshipnya dengan aktor membantu untuk menjelaskan struktur sistem pada use case. ${ }^{19}$

${ }^{19}$ Manajemen Resiko, Studi Kasus, and D I Pt, "DESAIN APLIKASI PENGENDALIAN KREDIT DAN BUMIPUTERA INDONESIA TBK,” 2008. 


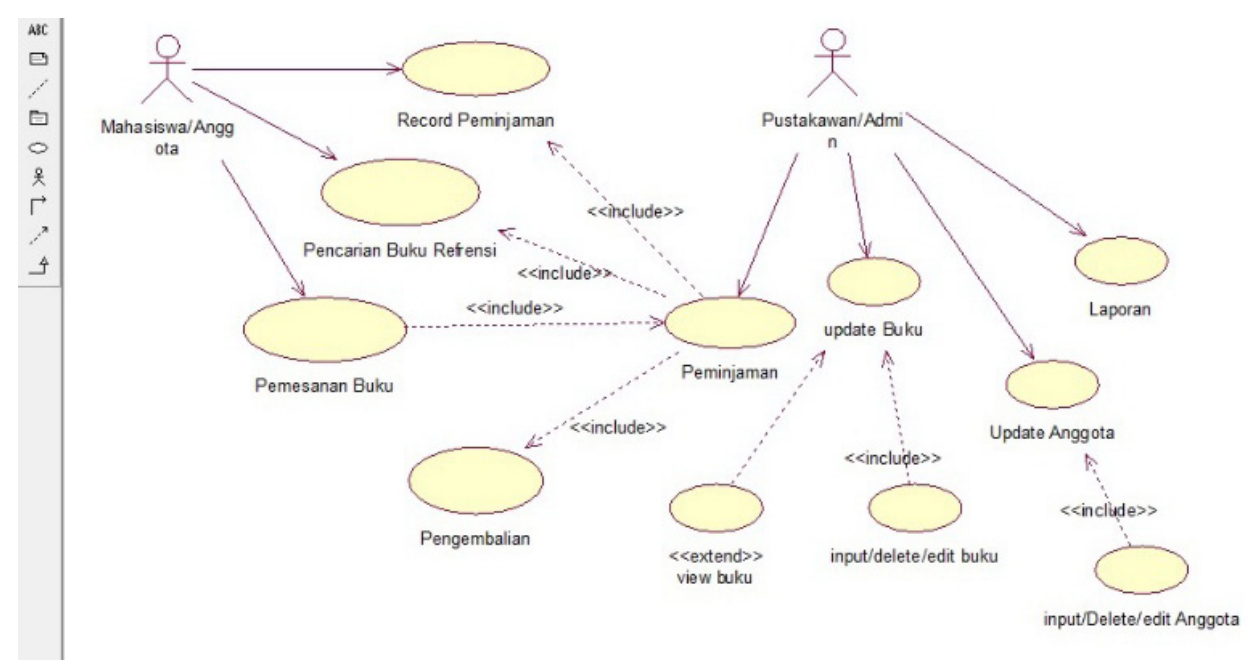

Gambar 7. Use Case Diagram

Tabel.1 Diskripsi Pengguna Use Case

\begin{tabular}{ccc}
\hline No & Pengguna & Deskripsi \\
\hline 1 & $\begin{array}{c}\text { Mahasiswa/ } \\
\text { Anggota }\end{array}$ & Mencari buku/jurnal berdasarkan refrensi yang di butuhkan. \\
\hline 2 & Pustakawan & $\begin{array}{l}\text { Melayani proses peminjaman dengan menginformasikan letak } \\
\text { dengan ada atau tidaknya buku/junal yang memiliki referensi } \\
\text { yang sesuai dengan kebutuhan }\end{array}$ \\
\hline
\end{tabular}

\section{Activity Diagram}

Activity diagram merupakan state diagram khusus, maka activity diagram tidak menggambarkan behaviour internal sebuah sistem (dan interaksi antar subsistem) secara eksak, tetapi lebih menggambarkan prosesproses dan jalur-jalur aktivitas dari level atas secara umum. Activity diagram merupakan gabungan dari beberapa teknik, yaitu: event diagrams oleh Jim Odell, SDL state modeling teknik,work-flow modeling, dan petri nets. Activity diagram menggambarkan berbagai alir aktivitas (workflows) dalam sistem yang sedang dirancang, bagaimana masing-masing alur berawal, decision 
yang mungkin terjadi, dan bagaimana mereka berakhir. ${ }^{20}$

Berikut alur diagram aktifitas dan dalam alur informasi untuk anggota dan admin. Dapat dilihat melalui diagram Aktivity pada gambar 8 dan 9.

Berikut alur diagram aktifitas dan dalam alur informasi untuk anggota dengan attribut record peminjaman, view buku refrensi, dan order buku. Dapat dilihat melalui diagram Aktivity pada gambar 8.

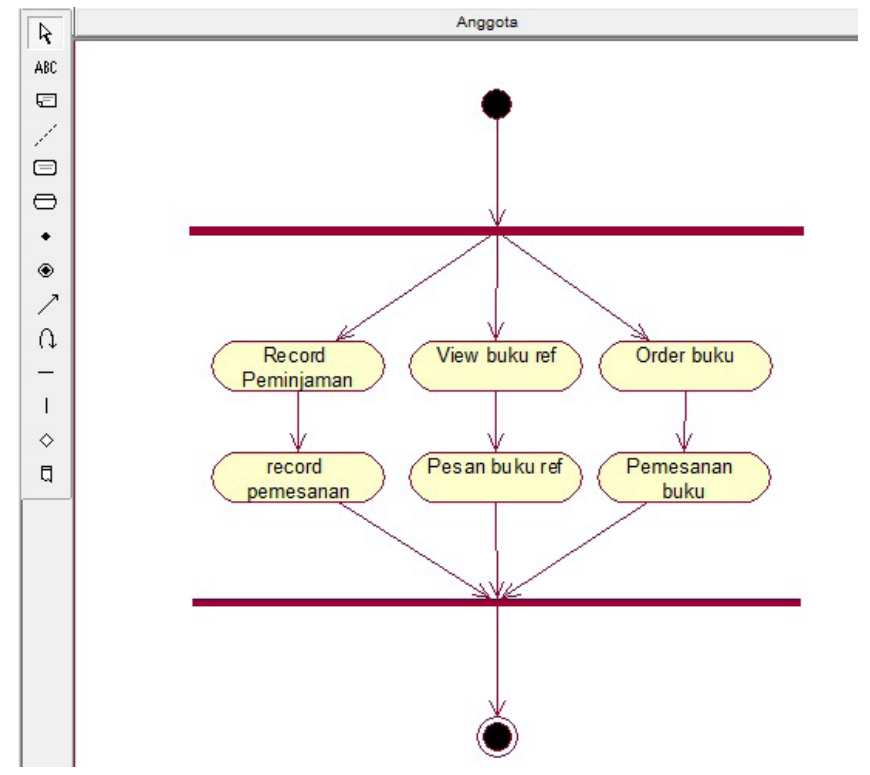

Gambar 8. Activity Diagram untuk Anggota

Berikut alur diagram aktifitas dan dalam alur informasi untuk admin dengan attribut Record peminjaman, View buku refrensi, dan Record Pesanan, Pesan buku Referensi. Dapat dilihat melalui diagram Aktivity pada gambar 9.

${ }^{20}$ Nyimas Sopiah, "Penggunaan Metode Analisis dan Rancangan Berorientasi Objek Pada Web Jurnal Ilmiah Terpadu," semnasIF 2012 2012, no. semnasIF (2012): 188-95. 


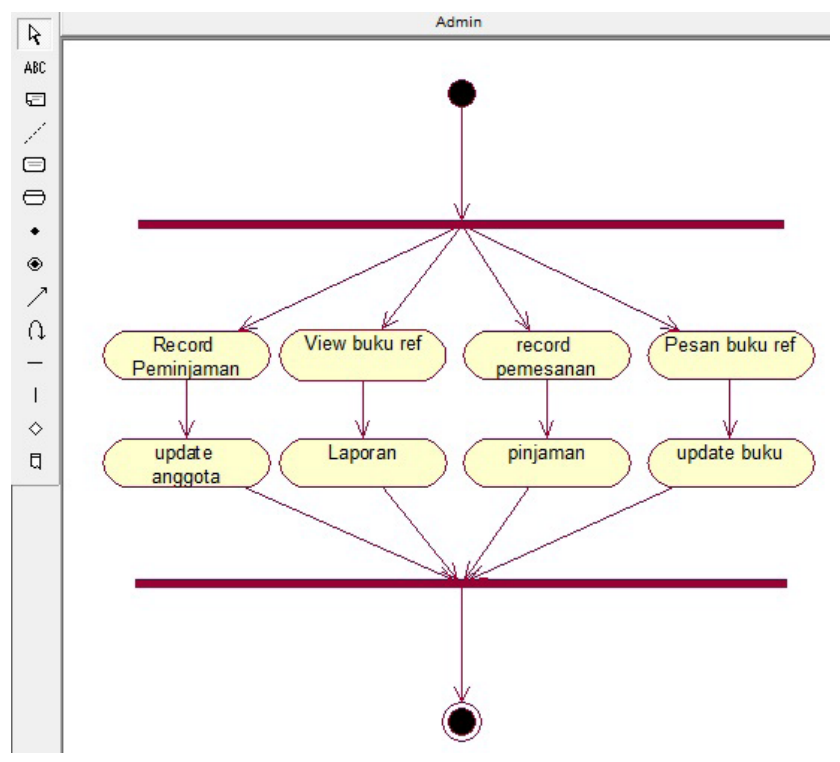

Gambar 9. Activity Diagram untuk Admin

\section{Class Diagram}

Class adalah sebuah spesifikasi yang jika diinstansiasi akan menghasilkan sebuah objek dan merupakan inti dari pengembangan dan desain berorientasi objek. Class menggambarkan keadaan (atribut/properti) suatu sistem, sekaligus menawarkan layanan untuk memanipulasi keadaan tersebut (metoda/fungsi).

Class diagram menggambarkan struktur dan deskripsi class, package dan objek beserta hubungansatu sama lain seperti containment, pewarisan, asosiasi, dan lain-lain. ${ }^{21}$

${ }^{21}$ Ilka Zufria et al., "Pemodelan Berbasis UML ( Unified Modeling Language ) Dengan Strategi Teknik Orientasi Objek User Centered Design ( UCD ..., no. January 2013 (2016). 


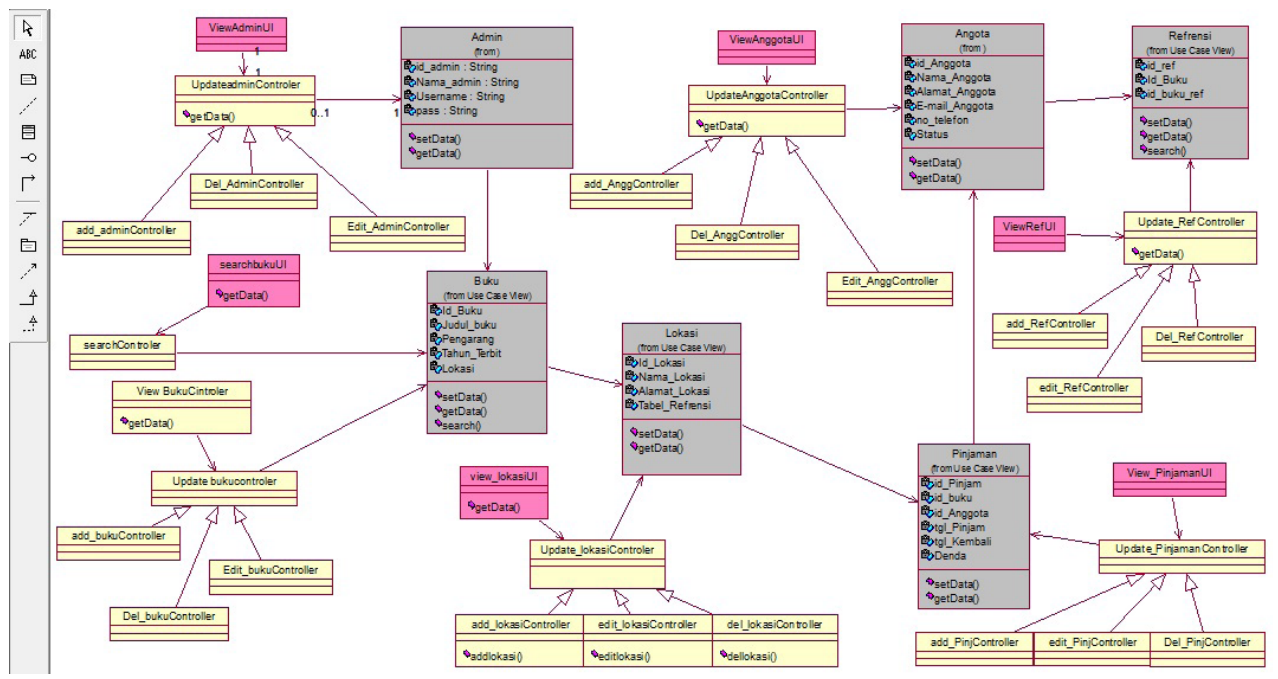

Gambar 10. Class Diagram Perpustakaan

\section{Implementasi Restful}

Membangun layanan dengan web service menggambarkan dari alur proses bisnis dari masing-masing bagian. Service yang dibangun berdasarkan parameter yang dibutuhkan dari masing-masing bagian yang langsung dengan software aplikasi lain dengan menggunakan message berbasis XML melalui protokol internet. Pesan yang disampaikan melalui XML/ JASON akan ditampilakan oleh elemen REST respon dan request. Dalam pengkasesan resource REST juga menggunakan URL dimana ada method yang di gunakan, dengan default adalah GET, PUT, DELETE, POST.

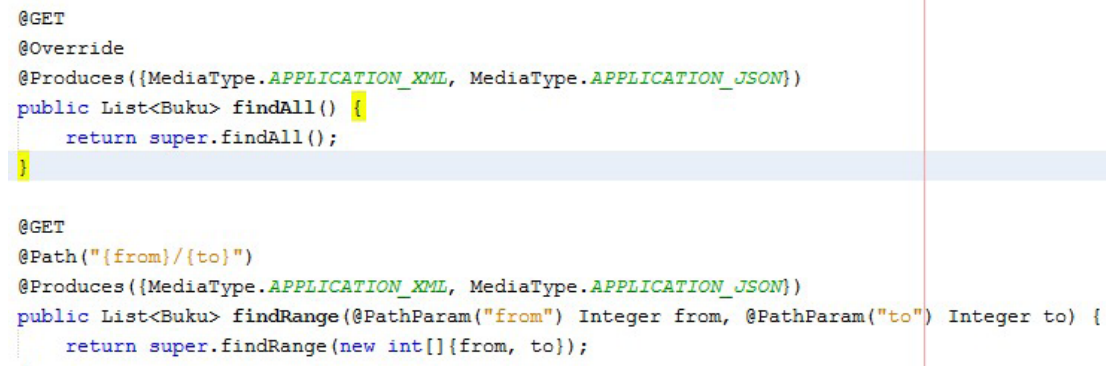


Perancangan Arsitektur RESTful pada Integrasi Data Refrensi Buku di Perpustakaan

Daerah dan Perpustakaan Universitas (Studi Kasus: Kota Salatiga)

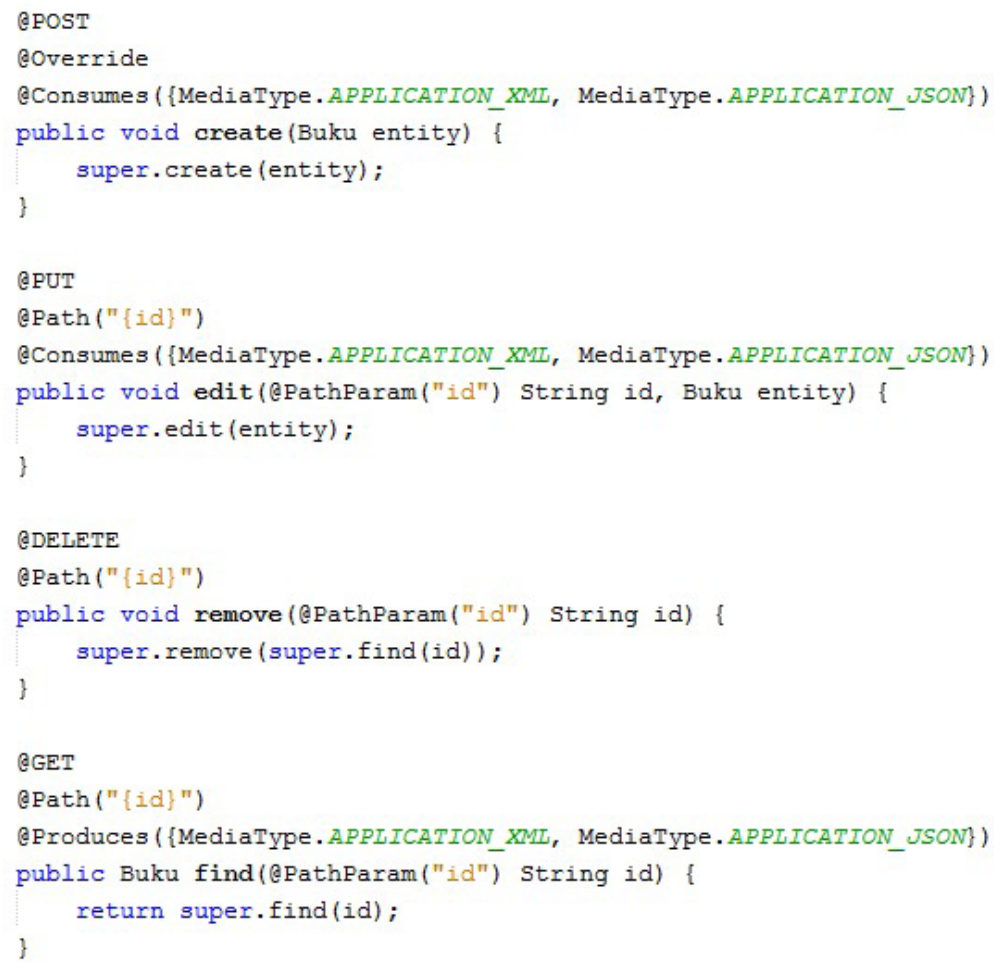

Gambar 11. Implementasi Restful

Hasil pengujian tahap simulasi dengan REST web service. Pada masing-masing bagian dapat diketahui dari proses inputan informasi dari tiap bagian yang dijadikan sebagai dasar untuk menentukan kebutuhan buku yang di jaiskan inputan, refreasni buku dan alamat lokasi. 


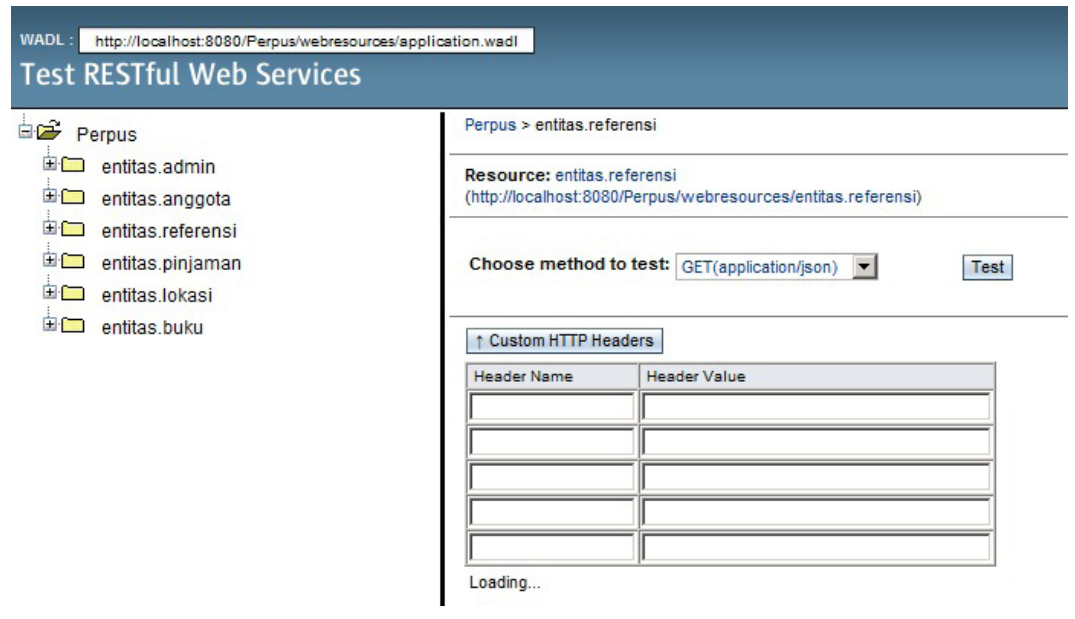

Gambar 12. Header Request

Proses uji coba diberikan beberapa skenario untuk mengetahui fungsionalitas fungsionalitas dari program. Uji coba dilakukan mulai dari masuknya input dan diproses sampai akhirnya menghasilkan output. Uji coba meliputi pengujian beberapa komponen utama dari simulasi aplikasi ini. Dalam hasil test yang di berikan pada proses request dan respon nya

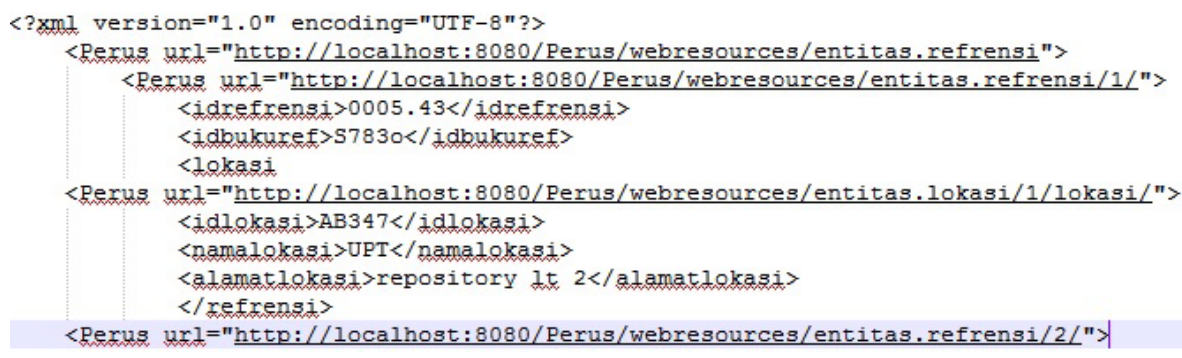

Gambar 13. Header Response

\section{Pembahasan}

Berdasarkan analisis dan perancangan yang dilaksanakan pada bab-bab sebelumnya dihasilkan service-service yang berbasis RESTful yang terdapat pada server dan aplikasi informasi tiap bagian admin atau 
pustakawan sebagai client pengguna service-service ini. Empat service utama dan method yang telah dihasilkan pada bab sebelumnya kemudian akan diuji dan diintegrasikan. Berikut hasil implementasi service-service tersebut:

1. @GET

@Get service ini berfungsi untuk mengabil resource yang hanya pelu di baca saja (Read Only) service list buku dari sisi server. Terdapat 2 method yang diimplementasikan yaitu method: Menampilkan harga pokok bahan. \{findRange (id)\} dan method: menampilkan data/resource. (getScheduleInfo)

2. @POST

@POST service ini berfungsi untuk mengupdate suatu resource dari kebutuhan yang harus di gunakan sebagai data inputan ke sisi server. Terdapat 2 method yang diimplementasikan yaitu method: Mengupdate data/resource $\{$ create (entity)\} dan method: Mengupdate data/resource. (getScheduleInfo)

3. @PUT

@PUT berfungsi untuk membuat atau create resource baru untuk kebutuhan yang harus di gunakan sebagai data inputan ke sisi server. Terdapat 2 method yang diimplementasikan yaitu method: Membuat data/resource baru \{edit (entity)\} dan method: Memebuat data/resource baru. (getScheduleInfo)

4. @DELETE

@PUT berfungsi untuk menghapus resource untuk kebutuhan yang tidak lagi harus di gunakan sebagai data inputan ke sisi server. Terdapat 2 method yang diimplementasikan yaitu method: Menghapus data/resource \{edit (entity)\} dan method: Menghapus data/resource. (getScheduleInfo)

Dari hasil web service yang di bangun dalam Perancangan Arsitektrur RESTful untuk integrasi data dari satu web service yang berisi banyak operation. Berdasarkan hasil yang telah dilakukan pada uji coba dan sudah di hasilkan berdasarkan implementasi. 1) Tiap bagian mendapatkan informasi data yang di butuhkan baik dari anggota dan admin sesuai dengan kebutuhannya 
berdasarkan web service, sehingga tidak lagi mendapat informasi data buku saja melainkan mengetahui list refrensi buku dan di lokasi buku referansi berada. 2) Bagian Admin dapat memberikan informasi dan memiliki data lokasi buku referansi baik di perpustakaan PT atau perustakaan daerah.

\section{Kesimpulan dan Saran}

Pada penelitian ini menyimpulkan beberapa hal dengan hasil yang telah dilakukan. Integrasi beberapa services yang berasal dari Membangun komunikasi dan menditribusikan data atau informasi antar sistem merupakan langkah yang dapat ambil untuk mengatasi permasalahan keterbatasan informasi. Langkah tersebut dapat dibuktikan dengan cara pembentukan arsitektur integrasi, penyediaan laman, ketersediaan informasi baik refrensi buku yang berkaitan dan lokasi buku sesuai refrensi buku yang di harapkan, proses yang memberikan kemampuan integrasi antar sistem yang dapat digunakan dalam menunjang setiap aktifitas dalam lingkungan kelompok maupun individu. RESTFul WS merupakan suatu cara yang dapat digunakan dalam mengintegrasikan sistem dan mendistribusikan data untuk sistem yang berbeda-beda. Dalam hal pengamanan sumberdaya, langkah yang dapat diambil yaitu dengan cara menggabungkan RESTFul.

Saran penulis antara lain: 1. Dalam melakukan analisa dan perancangan menggunakan prinsip-prinsip RESTful agar benar-benar memperhatikan proses bisnis yang ada supaya dihasilkan service yang dapat benar-benar independent atau tingkat kebergantungan antar service sangat kecil. 2. Service yang dihasilkan dalam penelitian ini dapat dikembangkan dengan perancangan dengan REST tahap lanjut untuk mengembangkan alamat lokasi buku refrensi yang ada di fakultas-fakultas di beberapa universitas.

\section{Daftar Pustaka}

Caeldries, F. "Reengineering the Corporation: A Manifesto for Business Revolution." Academy of Management Review 19, no. 3 (1994): 595600. https://doi.org/10.5465/AMR.1994.9412271824.

Christianto, Erwien, Wiranto Utomo, and Wiwin Sulistyo. "Data Integration 
of Cost Materials Needs through a Service Oriented Architecture (Study Case: Pt X Garment Ungaran)." Journal of Advanced Computer Science \& Technology 4, no. 1 (2015): 136-47. https://doi.org/10.14419/ jacst.v4i1.4309.

Dallas, Ian, and Moe Thandar Wynn. "Information Systems for Small and Medium-Sized Enterprises," 2014, 25-47. https://doi.org/10.1007/9783-642-38244-4.

Erl, Thomas. Service-Oriented Architecture: A Field Guide to Integrating XML and Web Services. Prentice Hall, 2004. http://scholar.google.com/sc holar?hl=en\&btnG=Search\&q=intitle:Service-Oriented+Architect ure+A+Field+Guide+to+Integrating+XML+and+Web+Services\#6.

HostBridge Technology. "Choosing Formal and Informal Web Services for." In SOAP and REST: Choosing Formal and Informal Web Services for CICS Integration, 2009. https://www.hostbridge.com/images/uploads/ WP_HostBridge_SOAP_and_REST_090303.pdf.

Laudon, Kenneth, and Jane P. Laudon. Management Information Systems, Global Edition, 2013. http://www.myilibrary.com/?ID=523735.

Mujab, Ahmad Isywarul, and Ary Setyadi. "Persepsi Pemustaka Terhadap Sikap Pustakawan Dalam Layanan Referensi Di Perpustakaan Universitas Katolik Soegijapranata" 4, no. 2 (2015).

Newcomer, Eric. Understanding Web Services: XML, WSDL, SOAP, and UDDI, 2004. http://restfulwebapis.org/RESTful_Web_Services.pdf.

Pautasso, Cesare, O. Zimmermann, and Frank Leymann. "Restful Web Services vs. 'Big'web Services: Making the Right Architectural Decision." Proceeding of the 17th International Conference on World Wide Web, 2008, 805-814. https://doi.org/10.1145/1367497.1367606.

Pressman, Roger S., and Bruce R. Maxim. Software Engineering: A Practitioner'S Approach., 2015. https://downloadnema.com/wpcontent/uploads/2017/02/Software Engineering A Practitioner's Approach eighth edition-(www.downloadnema.com).pdf.

Ramdani. "Pemanfaatan Koleksi Referensi Sebagai Sumber Daya Perpustakaan Dalam Jasa Layanan Informasi : Studi Kasus Pada Perpustakaan Mahkamah Konstitusi Republik Indonesia,” 2010. 
Resiko, Manajemen, Studi Kasus, and D I Pt. "DESAIN APLIKASI PENGENDALIAN KREDIT DAN BUMIPUTERA INDONESIA TBK,” 2008.

Sandoval, Jose. RESTful Java Web Services: Master Core REST Concepts and Create RESTful Web Services in Java. Vol. 11, 2009. https://books. google.com/books?id=NS6FeLs6hwMC\&pgis=1.

Sopiah, Nyimas. "Penggunaan Metode Analisis Dan Rancangan Berorientasi Objek Pada Web Jurnal Ilmiah Terpadu.” semnasIF 2012 2012, no. semnasIF (2012): 188-95.

Sousa, Pedro, Carla Pereira, Rute Vendeirinho, Artur Caetano, and Jose Tribolet. "Applying the Zachman Framework Dimensions to Support Business Process Modeling." Digital Enterprise Technology, 2005, 359-66. https://doi.org/10.1007/978-0-387-49864-5.

Tanaem, Penidas Fiodinggo. "RESTFul Web Service Untuk Sistem Pencatatan" 2, no. April (2016): 2443-2229.

Wijanarko, Andik, Irya Wisnubhadra, and Benyamin L Sinaga. "Integrasi Informasi Penelitian Pada Perpustakaan Perguruan Tinggi Berbasis Web Service," 2013, 7-12. https://www.google.co.id/url?sa=t\&rct=j\& $\mathrm{q}=\&$ esrc $=$ s\&source $=$ web\&cd $=1 \& \mathrm{cad}=\mathrm{rja} \& u a c t=8 \& \mathrm{ved}=0 \mathrm{ahUKEwjE}$ 5pTEwLjLAhUmIqYKHTE1BGcQFggZMAA\&url=http://e-journal. uajy.ac.id/341/1/0MTF01462.pdf\&usg=AFQjCNEEIBJ4K24hjwrewtn XbSvJWoVTxQ\&sig2=Wmy_qud3RGa9FX6R11Gwog\&bvm=bv.116.

Yudhistira, Elham, Aji Purwinarko, and Indah Urwatin Wusqo. "Implementasi Restful Web Service Menggunakan AsyncTask Pada Aplikasi Library Automation Berbasis Android," no. Snik (2016): 286-92. https://www.researchgate.net/profile/Aji_Purwinarko/ publication/310441851_Implementasi_Restful_Web_Service_ Menggunakan_AsyncTask_pada_Aplikasi_Library_Automation_ Berbasis_Android/links/582d2f3308ae102f072a1f5c/ImplementasiRestful-Web-Service-Menggunakan-.

Zufria, Ilka, Sumatera Utara, Medan Indonesia, Improve The Quality, and Top Management Decisions. "Pemodelan Berbasis UML ( Unified Modeling Language ) Dengan Strategi Teknik Orientasi Objek User Centered Design ( UCD ...," no. January 2013 (2016). 